\title{
LEONARDO MOREIRA
}

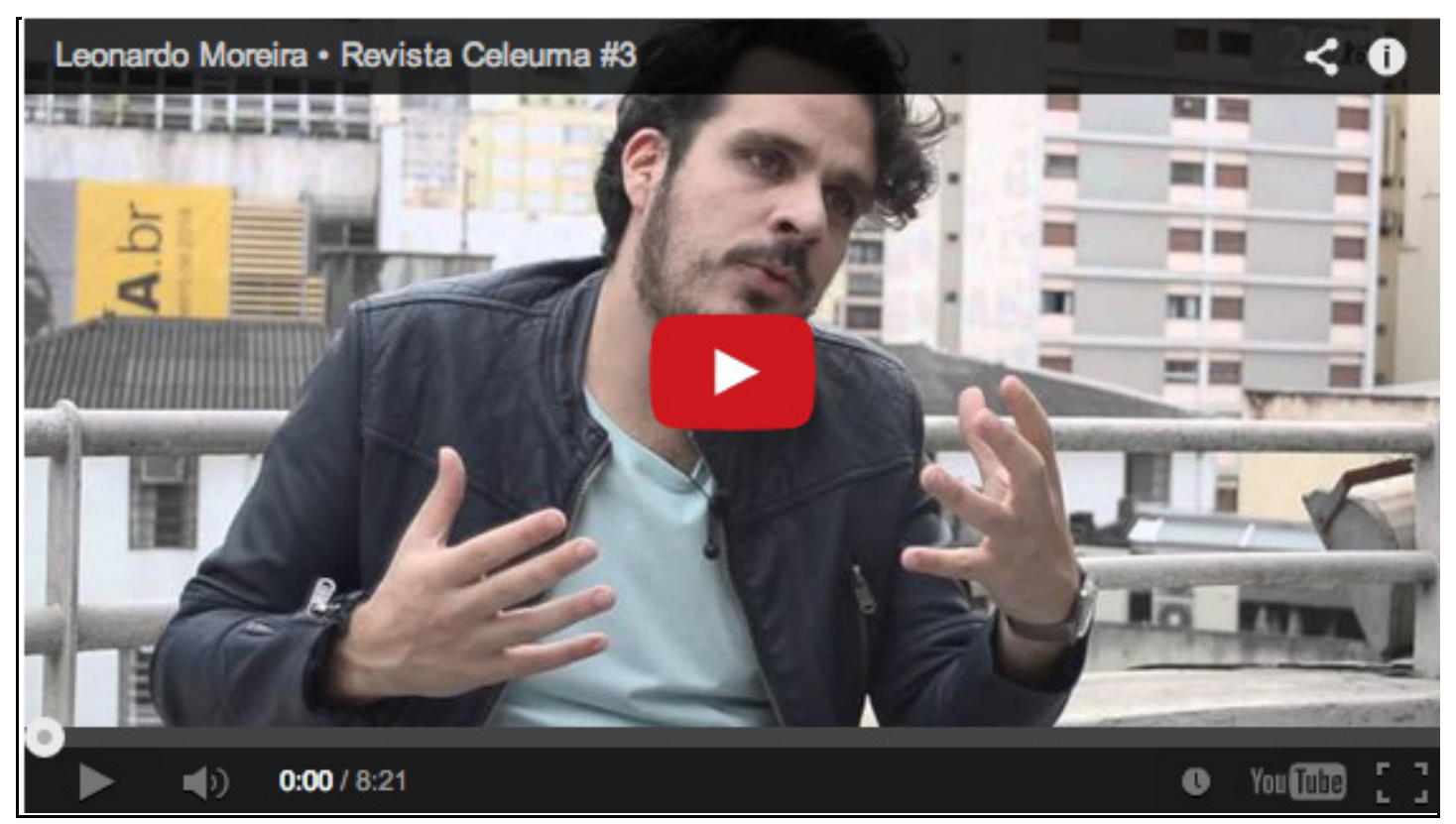

